\title{
A Study of the community based titre of the widal in Ahmedabad, India
}

\author{
Hetal Subodh Chandra Shah*
}

\author{
B-203, Parishram Tower, Mirambica road, Naranpura, Ahmedabad- 380013 Gujarat, India \\ *Corresponding author:
}

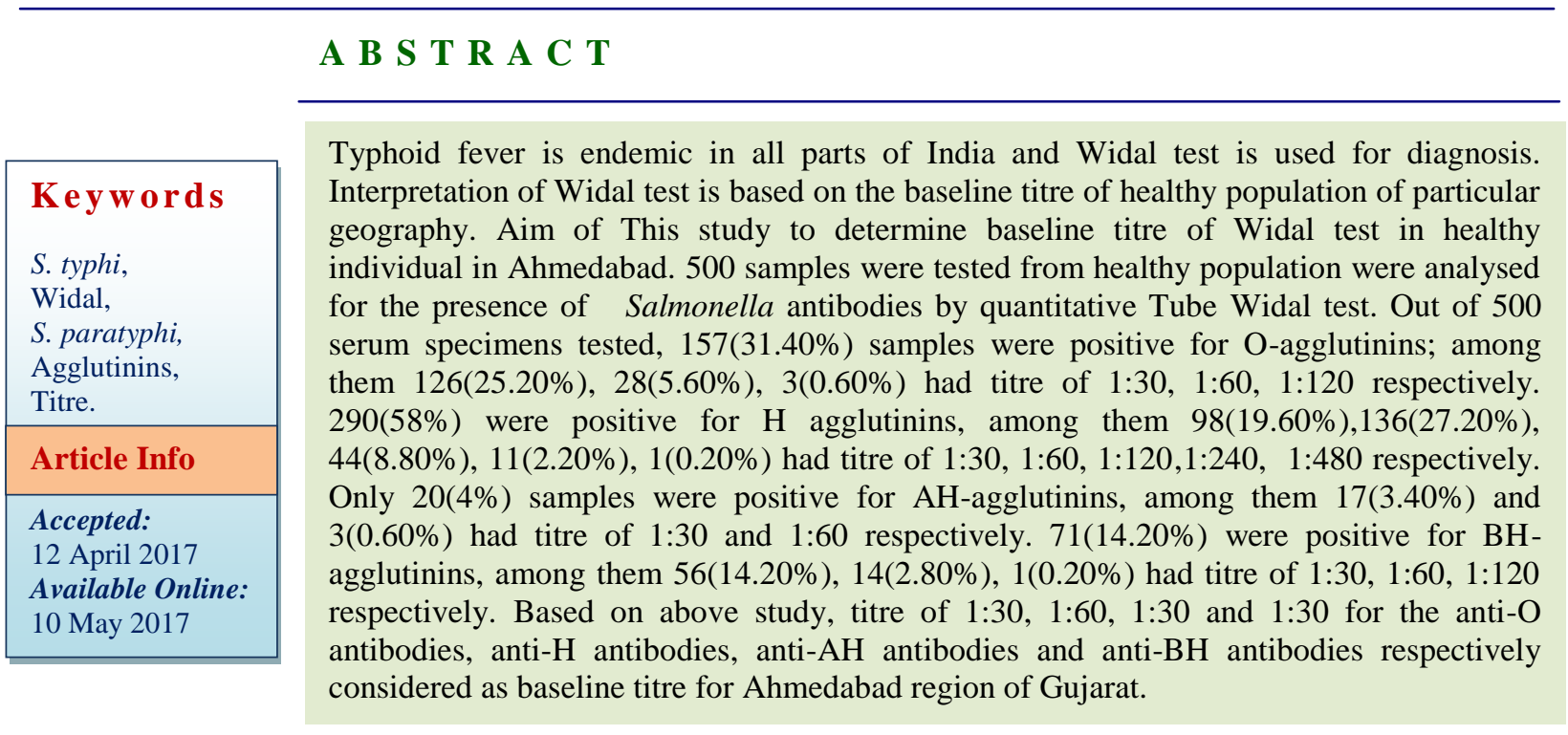

\section{Introduction}

Typhoid fever continues to be a global health problem, especially in tropics and subtropics (Hasan et al., 2011). Enteric fever is endemic in developing country like India and it continues to be one of the major health problem here (Kataria et al., 2013). The term enteric fever includes typhoid fever which is caused by $S$. typhi and Paratyphoid fever which is caused by $S$. paratyphi A, B and C (Punia et al., 2013).

Exposure of the individuals to contaminated food and water closely correlate with the risk of enteric fever (Chowta et al., 2005). Typhoid fever is a febrile illness of prolonged duration characterized by step ladder fever, diffuse abdominal pain, frontal headache, delirium, splenomegaly, hepatomegaly and many other systemic manifestations due to septicaemia and bacteraemia (Vazhavandal et al., 2014).

Definitive diagnosis of enteric fever depends on isolation of Salmonella from blood, stool, urine, bone marrow, bile or other body fluids. However, in countries like India, isolation of organism is often jeopardized by lack of facilities or inadequate and / or improper antibiotic use prior to culture. Culture is time consuming and expensive. For these reasons, laboratory diagnosis of enteric fever relies heavily on serological tests such as the Widal 
test The test becomes reliable if at least two properly staged tests show about a four-fold rise in antibody levels. In India, most of the patients present late to the hospital and they require an intermediate diagnosis and a specific treatment and often, a single sample has to be relied upon, instead of paired serum samples. And so, a single cut-off value is widely used (Gunjal et al., 2013). The interpretation of Widal test depends upon the baseline titre which is prevalent amongst the healthy individual in particular geographical area. The Widal titre among the healthy populations of different areas differs substantially and this depends upon the endemicity of typhoid in each area, which has been changing over time. Updating the baseline Widal titre is a must for the proper interpretation of Widal test (Peshattiwar, 2012).

Although Widal test is widely used in our region for the diagnosis of typhoid fever, as far our knowledge, no previous attempts were made in this region to estimate the community based antibody titre in the healthy population. Hence the study was undertaken to determine the baseline Widal titre in single serum in and round Ahmedabad.

\section{Materials and Methods}

This prospective cross sectional study was conducted in the department of Microbiology, GMERS Medical College and Hospital, Sola, Ahmedabad, Gujarat from January 2013 to March 2013. This is tertiary care and multi speciality Hospital affiliated with Medical College. Total 500 samples were collected from healthy persons who has not immunised with typhoid vaccines, did not suffering from fever within last three months, which are living in and around Ahmedabad area. None of the healthy persons had history of Malaria, Filaria, HBsAg, HIV and HCV infection in the past. Informed consent was taken from each participant. Serum was separated and the sera were tested by tube agglutination test for detection of specific antibodies of $\mathrm{O}, \mathrm{H}, \mathrm{AH}$ and $\mathrm{BH}$ antisera as per the manufacturer's instructions (Immunopak, Reckon Diagnostics P. Ltd.) The Widal tube agglutination was performed using dilutions from 1:30 to $1: 480$ with $\mathrm{O}, \mathrm{H}, \mathrm{AH}$ and $\mathrm{BH}$ antigens in the kit. For tube Widal test, floccular cottonwool type is considered as positive $\mathrm{H}$ antigen and granular and mat type at the bottom of the tube is considered as positive $\mathrm{O}$ antigen. The highest dilution of serum which shows visible distinct agglutination was noted as a titre for Widal test.

\section{Results and Discussion}

Out of 500 healthy persons, 259 (51.80\%) were male and $241(48.20 \%)$ were female with M: F ratio 1.07: 1. Age of the study ranges from 14 years to 65 years with the mean age of 45.94 years, out of 500 persons, $35.40 \%$ of the persons belonged to the lower socio economic status, $23.40 \%$ belonged to the middle socio economic status and $41.20 \%$ belonged to the upper socio economic status.

Table 1 shows that out of total of 500 healthy persons, $157(31.40 \%)$ samples were positive for the $\mathrm{O}$ agglutinins, among them $126(25.20 \%)$ samples had a titre of $1: 30$, $28(5.60 \%)$ samples had a titre of 1:60 and $3(0.60 \%)$ samples had a titre of 1:120.

Out of total 500 samples, 290(58\%) were positive for the $\mathrm{H}$ agglutinins, among them $98(19.60 \%)$ samples had a titre of 1:30, $136(27.20 \%)$ samples had a titre of 1:60, $44(8.80 \%)$ samples had a titre of $1: 120$, $11(2.20 \%)$ samples had a titre of 1:240 and $1(0.20 \%)$ sample had a titre of $1: 480$

20(4\%) samples were positive for the $\mathrm{AH}$ agglutinins, among them $17(3.40 \%)$ samples 
had a titre of $1: 30,3(0.60 \%)$ samples had a titre of 1:60. 71(14.20\%) samples were positive for the $\mathrm{BH}$ agglutinins, among them $56(14.20 \%)$ samples had a titre of $1: 30$, $14(2.80 \%)$ samples had a titre of $1: 60$ and $1(0.20 \%$ ) sample had a titre of 1:120 (Table 2).

The isolation of the various strains of Salmonella enterica subspecies enterica from blood remains the gold standard for the diagnosis of enteric / typhoid fever. However, in the modern era, there is an alarming upsurge in the empirical use of broad spectrum antibiotics, the practice of self medication, the lack of proper timing for the specimen collection and more time consuming that attributes to the reduced productivity of the blood culture technique (Sharma et al., 2013). Lack of improper timing of sample collection and initiation of antibiotic therapy before diagnosis is made could be one of the major reasons for poor isolation rates (Kogekar et al., 2015). Also in the developing countries, such as the Indian subcontinent, many clinics and hospitals do not have a ready access to the blood culture method, thus making the Widal tube agglutination test the most common alternative laboratory procedure for the diagnosis of enteric fever. Serological diagnosis relies classically on the demonstration of rising titre of antibodies in paired samples, 10 to 14 days apart. In typhoid fever, however, such a rise is not always demonstrable, even in the blood culture confirmed cases. Furthermore, the patient treatment cannot wait for long. For practical purpose, the treatment decision must be made on the basis of the results which are obtained with a single acute phase sample (Parry et al., 1999). But the majority of the normal healthy individual in endemic region also carry detectable antibodies due to the repeated prior exposure with low inoculums of typhoid bacilli, the knowledge of baseline titre is important for using the Widal test as diagnostic tool for enteric fever in endemic area (Pal et al., 2014). The cut off titre in a particular population depends on the background level of the typhoid antibodies and the levels of the typhoid vaccination, which may vary with time. The variation depends on the degree to which typhoid is endemic in each area. So, each country or region should have a baseline titre of their healthy population, which should be updated with time (Pal et al., 2013).

Table.1 Different baseline titre values in India states

\begin{tabular}{|c|c|c|c|c|c|c|}
\hline \multirow[t]{2}{*}{ Authors } & \multirow[t]{2}{*}{ Place } & \multirow[t]{2}{*}{ Year } & \multicolumn{4}{|c|}{ Baseline titre } \\
\hline & & & TO & $\mathrm{TH}$ & $\mathrm{AH}$ & $\mathrm{BH}$ \\
\hline Shekhar Pal ${ }^{8}$ & $\begin{array}{l}\text { Garhwal } \\
\text { (Uttarakand }\end{array}$ & 2011 & $1: 40$ & $1: 80$ & $1: 20$ & $1: 20$ \\
\hline Peshattiwar $^{7}$ & $\begin{array}{l}\text { Amalpuram } \\
\text { (Andhra } \\
\text { Pradesh) }\end{array}$ & 2012 & $1: 40$ & $1: 40$ & $1: 20$ & 0 \\
\hline $\begin{array}{l}\text { Madhusudhan } \\
\mathrm{NS}^{9}\end{array}$ & $\begin{array}{l}\text { Hubli- } \\
\text { Dharwad } \\
\text { (North } \\
\text { Karnataka) }\end{array}$ & 2012 & $1: 40$ & $1: 80$ & $1: 40$ & - \\
\hline Saxena. $^{10}$ & $\begin{array}{l}\text { Hadoti } \\
\text { Region } \\
\text { (Rajasthan) }\end{array}$ & 2012 & $1: 40$ & $1: 40$ & $1: 20$ & $1: 20$ \\
\hline Present study & Ahmedabad & 2013 & $1: 30$ & $1: 60$ & $1: 30$ & $1: 30$ \\
\hline
\end{tabular}


Table.2 Distribution of positive $\mathrm{O}, \mathrm{H}, \mathrm{AH}$ and $\mathrm{BH}$ samples by Tube Widal test

\begin{tabular}{|l|l|l|l|l|}
\hline $\begin{array}{l}\text { Agglutinating } \\
\text { titre(tube) }\end{array}$ & $\begin{array}{l}\text { Frequency } \\
\text { \& } \\
\text { Percentage } \\
\text { TO }\end{array}$ & $\begin{array}{l}\text { Frequency } \\
\text { Percentage } \\
\text { TH }\end{array}$ & $\begin{array}{l}\text { Frequency } \\
\text { \& } \\
\text { Percentage } \\
\text { AH }\end{array}$ & $\begin{array}{l}\text { Frequency } \\
\text { \& } \\
\text { Percentage } \\
\text { BH }\end{array}$ \\
\hline $1: 30$ & $126(25.20 \%)$ & $98(19.60 \%)$ & $17(3.40 \%)$ & $56(14.20 \%)$ \\
\hline $1: 60$ & $28(5.60 \%)$ & $136(27.20 \%)$ & $3(0.60 \%)$ & $14(2.80 \%)$ \\
\hline $1: 120$ & $3(0.60 \%)$ & $44(8.80 \%)$ & $0(0 \%)$ & $1(0.20 \%)$ \\
\hline $1: 240$ & $0(0 \%)$ & $11(2.20 \%)$ & $0(0 \%)$ & $0(0 \%)$ \\
\hline $1: 480$ & $0(0 \%)$ & $1(0.20 \%)$ & $0(0 \%)$ & $0(0 \%)$ \\
\hline Total & $157(31.40 \%)$ & $290(58 \%)$ & $20(4 \%)$ & $71(14.20 \%)$ \\
\hline
\end{tabular}

The results of this study showed that the sera of a significant proportion of healthy individuals in this area contained antibodies which were capable of reacting to the variable titres in the Widal test. In our study, we observed that majority of study population has baseline titre for $\mathrm{O}, \mathrm{H}, \mathrm{AH}$ and $\mathrm{BH}$ antigen is $1: 30,1: 60,1: 30$ and $1: 30$ respectively. Significant titre is more than the baseline titre. It means the significant titre for $\mathrm{O}, \mathrm{H}, \mathrm{AH}$ and $\mathrm{BH}$ agglutinins were 1:60, 1:120, 1:60 and 1:60 respectively.

Our results were in concordance with those of the study which was reported by Shekhar Pal in Garhwal region of Uttarakhand, India and Madhusudan in Hubli (2012). Both the author shows that titre for $\mathrm{TH}$ is elevated more $(1: 80)$ than other agglutinins. Our study also shows titre for $\mathrm{TH}$ is 1:60 which more than other agglutinins like $\mathrm{TO}, \mathrm{AH}$ and $\mathrm{BH}$. Difference in the titre level from our study may be due to selection of different kits. Several other factors may have contributed to this discrepancy. The differences in the antibody response may be due to poorly standardised antigen preparation and sharing of antigen determination with other Salmonella. Other reasons may due to variation in different geographical area. Several studies have highlighted the limitations of using the Widal serological test in the laboratory diagnosis of Salmonella, the worst being its non specificity.
Despite this fact, considering the low cost, rapid test and the absence of comparatively cheap tests, the Widal tube agglutination test is likely to remain the test of choice in many developing countries, as of ours, provided a baseline antibody titre of healthy individual in the population, is known.

It is concluded, that even today, the Widal test remains one of the best, easily accessible, cheap and simple method for the diagnosis of typhoid fever. Single Widal test in a febrile patient would serve as presumptive evidence of infection if carefully interpreted based on prevalent local baseline titre.

Any titre above the baseline titre can be taken as a significant titre for the diagnosis of enteric fever. In our study, baseline titre for $\mathrm{O}$, $\mathrm{H}, \mathrm{AH}$ and $\mathrm{BH}$ antigen is 1:30, 1:60, 1:30 and $1: 30$ respectively. It has been recommended that the significant titre of the $\mathrm{O}$ agglutinins and $\mathrm{H}$ agglutinins of Salmonella typhi, Salmonella paratyphi $\mathrm{AH}$ and paratyphi $\mathrm{BH}$ is $1: 60,1: 120,1: 60$ and 1:60 respectively for area in and around Ahmedabad region. So, we recommend changing currently used baseline titre of Widal test in Ahmedabad.

Salmonella agglutinins are common among apparently healthy people and as endemicity of typhoid in an area may change over time, more studies should be carried out to 
determine Salmonella agglutinin titre in apparently population, so that a better judgement for agglutinin titre can be made.

\section{Acknowledgment}

We are thankful to the Superintendent, GMERS Medical College and hospital, Sola for their support in the work.

\section{References}

Chowta, M.N., Chowta, N.K. 2005. A study on the clinical profile and the antibiotic response in typhoid fever. Indian J. Med. Microbiol., 23: 125-27.

Gunjal, S.P., Gunjal, P.N., Patil, N.K., Vanaparthi, N., Nalawade, A.V., Swati Banerjee, S. et al. 2013. Determination Of Baseline WidalTitres Amongst Apparently Healthy Blood Donors In Ahmednagar, Maharashtra, India. J. Clin. Diag. Res., 7(12): 2709-2711.

Hasan, A.S., Abbas, A.A., Abbas, F.A. 2011. The Distribution of Anti-Salmonella Antibodies in the Sera of Healthy Blood Donors in Baquba city. Iraqi J. Comm. Med, 24(3): 241-44.

Kataria, V.K., Bhai, N., Mahawal, B.S., Roy, R.C. 2013. Determination of baseline Widal titre among apparently healthy population in Dehradun City. IOSR J. Pharmacy and Biol. Sci., (IOSR-JPBS), 7(2): 53-55.

Kogekar, S., Peshattiwar, P., Jain, K., Rajput, M., Shahi, P.K. 2015. Study of baseline Widal titre amongst healthy individuals in and around Indore, India. Int. J. Curr. Microbiol. App. Sci., 4(7): 775-778.

Madhusudan, N.S., Manjunath, A.H. 2012. Determination of baseline Widal titre among healthy population. Int. J. Biomed. Res., 3(12): 437-8.

Pal, M., Mitra, R., Datta, S., Mondal, M. 2014. Determination of baseline titre of Widal test among healthy population in eastern part of India. World J. Pharmaceutical Res., 3(3): 4728-38.

Pal, S., Prakash, R., Juyal, D., Sharma, N., Rana, A., Negi, S. 2013. Baseline Widal Titre in Hilly Areas of Garhwal Region of Uttarakhand, India. J. Clin. Diag. Res., 7(3): 437-440.

Parry, C.M., Hoa, N.T., Diep, T.S., Wain, J., Chinh, N.T., Vinh, H., et al. 1999. The value of a single tube Widal test in the diagnosis of typhoid fever in Vietnam. J. Clin. Micro., 37(9): 2882-85.

Peshattiwar, P. 2012. Study of the Baseline Widal Titre amongst Healthy Individuals in Amlapuram, India. J. Clin. Diag. Res., 6(3); 416-417.

Punia, J.N., Joshi, R.M., Gupta, V., Arora, R.K. 2013. Determination of the baseline Widal titre in Chandigarh. Ind. J. Med. Microbiol., 21(2): 144.

Saxena, N., Maheawari, D. and Dadhich, D. 2012. Baseline widal titres among apparently healthy individuals in Hadoti region, Rajasthan. J. Evol. Med. Dent. Sci., 2(15): 2425-29.

Sharma, S., Singh, A., Parihar, G. and Verma, A. 2013. The baseline widal titre among the healthy volunteers in Jaipur region Rajasthan, India. IJRRPAS, 3(5): 667-672.

Vazhavandal, G., Bharadwaj, V.G.B., Vasudevan, K., Sarada, V. and Uma, A. 2014. A Study on the Baseline Widal Titre amongst Healthy Individuals in Trichy, India J. Biol. Chem. Res., 31(1): 220-225.

\section{How to cite this article:}

Hetal Subodh Chandra Shah. 2017. A Study of the community based titre of the widal in Ahmedabad, India. Int.J.Curr.Microbiol.App.Sci. 6(5): 1145-1149. doi: https://doi.org/10.20546/ijcmas.2017.605.124 